\title{
POTENTIAL FOR COLLABORATION AS SUPPORT FOR AIRPORT MANAGEMENT (ON THE EXAMPLE OF RADOM AIRPORT)
}

\author{
Dorota Rajkowska
}

Radom Airport

\begin{abstract}
Collaboration is a measurable effect of joint action, while its occurrence is closely related to the development of an organization. The author presents it as the element of management. The article is based on the concepts of identification and measurement of the potential for collaboration. An analysis of the organization's collaborative potential is presented on the example of Radom Airport. It is based on the methodology of researching the organization's potential for external collaboration constructed on the basis of the classic organization model according to H.J. Leavitt. The specified model was the basis for the development of a questionnaire, based on the grades in the 5-point Likert scale, thanks to which it was possible to assess the level of organization preparation for collaboration at a given stage.
\end{abstract}

Keywords: management, cooperation, collaboration, potential, airport

DOI: $10.17512 /$ znpcz.2018.1.19

\section{Introduction}

Management in a contemporary organization develops and changes. The area that stimulates the changes in management is the development of knowledge and the flow of information. An important element that affects the perception of this process and the changes in it is the environment that requires joint action. The concept of collaboration between independent enterprises is a key element in the development of each enterprise. They implement the economic activity adopted by the market and strive to achieve various objectives. The essence, the character, and the forms of relations between them are the subject of the analysis described in literature on either a theoretical or a practical basis (Zachorowska 2006, p. 58; Daft 2012, p. 7; Nowicka 2011, p. 2-9; Levi, Devis 2008, p. 2180; Krzywda, Krzywda 2015, p. 75; Kalmi 2007, p. 625). They are closely related to the level of employment and increase in turnover. However, collaboration with companies from a particular sector has a strong positive relationship with the increase in profitability (Robson, Bennett 2000).

The existence of agreements and collaboration between various participants of the market explains the transaction costs theory, which emphasizes the importance of operating costs reduction (Heiman, Nickerson 2002, p. 97-116). From the perspective of management, the value chain concept of the M.E. Porter is important. He considers external chain management as the source of added value. 
M. Romanowska and M. Trocki $(2002$, p. 16) believe that in this case, it is not only about the benefits of good economic collaboration, but also about taking over the added value skilfully by negotiating and using synergy effects.

Collaboration is a measurable effect of joint action, while its occurrence is closely related to the development of the organization (Surowiec 2015, p. 157; Ejdys, Ustinovicius, Stankeviciene 2015, p. 269). It can also be seen as a management tool (Pierścieniak 2016, p. 201). In an organization providing services (such as an airport), collaboration is a key element of functioning. Each manager should be aware that his effectiveness is important for the development of the company and the decision-making processes are conditioned by its development. In the light of these premises, it is worth considering how collaboration is related to the management process and how the organization can prepare to implement effective collaboration that will enable it to develop.

One type of an organization whose operations is based on cooperation is an airport. An airport as an organization has to carry out the development process using the support of other organizations and closely collaborate with them. Recognizing the potential for collaboration is important for the efficient operation of the airport. This information is important for the management process.

The article aims to identify the potential for collaboration of the airport and to connect its role with the management process.

The methodology used in this article is based on the concepts of identification and measurement of the organization's potential for collaboration contained in A. Pierścieniak (2015) in a book The Organization's Potential for External Collaboration - Theoretical Approach and Measurement Methodology. The analysis used deductive methods, indicative methods, and a questionnaire to diagnose individual elements of the studied phenomenon. The subject for research was chosen deliberately, using the criterion of the airport and guided by the availability of data. The case study is based on a diagnosis of the organization condition.

\section{Collaboration and airport management}

Each company operates in a specific environment. It is recorded in literature in various ways. For example, L. Nieżurawski (2005) understands it as all phenomena, processes, and institutions shaping its interchangeable relations, sales opportunities and forms of operation, as well as development conditions. The environment here is the internal environment of the company and all elements that are not part of the company's system but are related to it and affect its state, or whose state is affected by the airport.

All factors representing surroundings understood in this way have been grouped in two areas. The external environment, further called macro-generation and the general environment, includes elements which affect the company and its relations with recipients, but the enterprise itself has no possibility of influencing them. In the study area, six types of surroundings were also distinguished. They include economic, political, legal, international, technical and technological environments as well as the external environment, which is the competitive environment. The target environment 
was also distinguished, the elements of which affect the company and its market relationships, but the enterprise itself has the possibility of influencing them, so it receives some feedback. This environment is represented by recipients, competitors, suppliers, etc. E. Porter limits the competitive environment to the sector (Porter 1999). On the other hand, the remaining elements of the near environment, mainly related to the supplier's relationship, the recipient, and the non-sectoral environment, are factors shaping the attractiveness of a given sector for potential investors. For this reason, three groups of factors were identified in this area related to the situation of the sector, trends shaping the sector and relations between its participants and other elements of the competitive environment. However, factors representing the external environment do not exhaust the list of all determinants affecting the choice of forms of collaboration. In addition to the external environment, both far and near, R.W. Griffin (1998) additionally distinguishes the so-called internal turning of an organization whose main components are management, employees, and organizational culture. Therefore, the third area of searching for factors is the internal environment, which is the set of the company's potential, taking into account its strengths and weaknesses, which may become the reason for a possible success or failure on the market (Marek 1999). The concept of business management is an intentional process, the development of which indicates the common occurrence of such features as purposefulness (Drucker 2002, p. 85; Illés, Dunay, Jelonek 2015, p. 48; Seroka-Stolka, Krawczyk-Sokołowska, Grabowska 2016, p. 122). The development of science means that today we understand the way of achieving the goal as actions focused not only on the classic management functions identified by, J. Stoner, E. Freeman, D. Gilbert Jr (Stoner, Freeman, Gilbert 2011, p. 62).

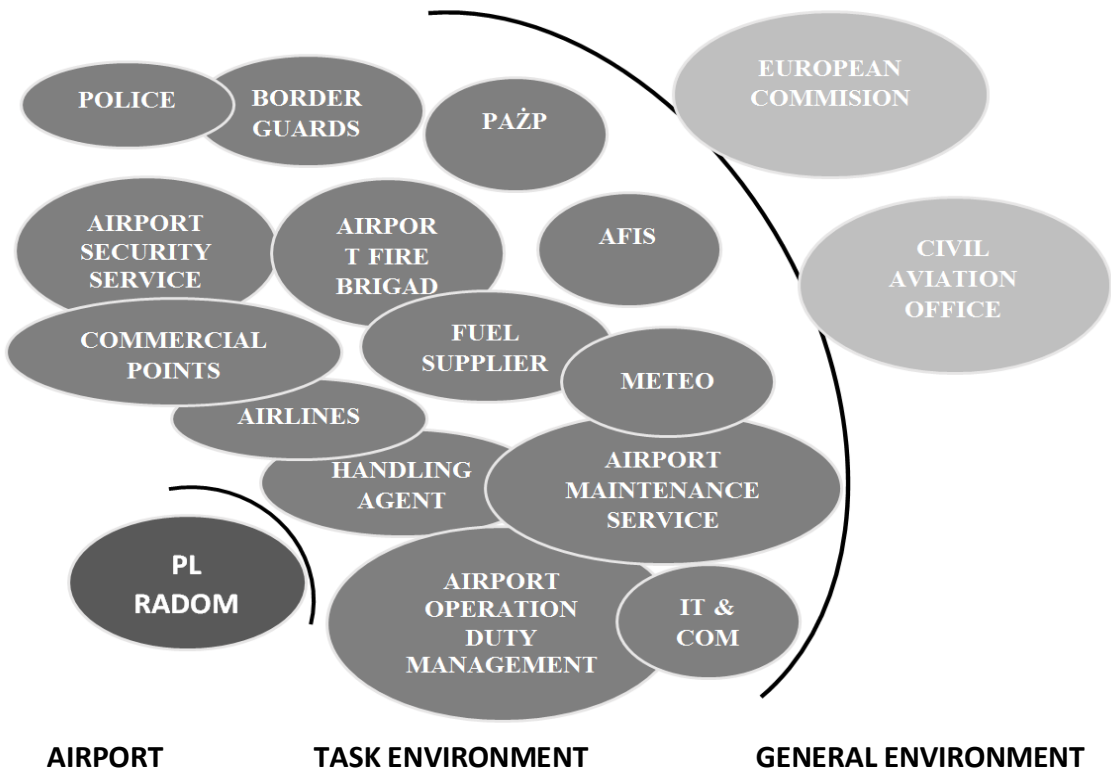

Table 1. The institutional environment of Radom Airport - collaboration actors Source: Own elaboration 
Management is perceived today in a broader sense, and contemporary definitions are very abstract. A.K. Koźmiński said that the essence of management is to control diversity and transform a potential conflict into collaboration. He also explains that collaboration is not limited to the interior of the organization, but it must also include relations with external entities and aims to ensure the organization's survival and development. It consists in ensuring (conscious creation) appropriate conditions for the organization to act in accordance with its assumptions - it fulfills its mission, achieves its goals and maintains the necessary level of cohesion, enabling ongoing functioning and further stable development. The power of collaboration is taken from their multidimensionality (Pierścieniak 2014, p. 92).

According to the concept mentioned above of the management process, collaboration is a tool for creating relations, and without it, a modern enterprise does not function. Every enterprise, including the airport, cooperates with the environment. It is the environment which directly collaborates with the airport and further defines how the airport should operate (Figure 1). Most airports in Poland, in addition to collaboration with airlines, base their operational activities on collaboration with external organizations providing airport security services and handling services for passengers and planes. The schematic diagram of Radom Airport environment is shown in Figure 1.

The immediate surroundings of the airport are organizations and cells directly affecting the airport. The correctness and safety of flight operations depend on them. This dependence is also reversed because the airport creates an environment in which they can function. These cells are either external organizations, or they directly belong to the airport's organizational structure, depending on their size. The general environment includes organizations that create laws and regulations which regulate its functioning and which it is obliged to observe.

\section{Characteristics of Radom Airport's collaboration in the context of management processes}

The airport is an organization which is potentially determined by the maximum airport capacity, which is the number of passengers and aircraft accepted at a given time. Radom Airport could be the strategic point for the economic development of Radom city and the surrounding areas in the future. It could offer the potential to service other urban agglomerations, including Warsaw. On the one hand, the growing number of passengers will force the necessity of additional expansion of the infrastructure around the airport directly connected with it, such as parking lots, access roads, public transport elements. On the other hand, the development of Radom Airport will affect the development of related services such as hotels, catering facilities, commercial buildings, offices, and tourist agencies. The strategic goal of the development of Radom Airport is to achieve the status of a stable regional international airport constituting a support airport for Warsaw - Okęcie airport and being a stimulator of the development of the city of Radom and Radom sub-region. 
The airport in Radom has all the services guaranteeing the efficient operation of the company in its structures. The collaboration of Radom Airport with external entities is based mainly on its collaboration with airlines. It applies to efficiently checked passengers as well as loading and unloading luggage from and to the aircraft, and safe take-off and landing of planes. The quantitative effects of collaboration are identified by the growing number of passengers. Another element is the qualitative dimension of collaboration, in which one of the areas is preparing the organization for collaboration.

\section{Research methodology}

The analysis of the organization's preparation for collaboration, or the cooperative potential of Radom Airport, is based on the methodology of researching the organization's potential for external collaboration, which was constructed on the basis of the classical organization model according to H.J. Leavitt. In the concept of collaborative potential, A. Pierścieniak (2015) distinguished eleven basic elements of potential, grouped in five main areas, which each organization has. In the area of goals and tasks, there are such elements as strategic planning of teamwork (E1). The area of technology is divided into know-how understood as activities supporting the collaboration process implemented in the organization of dry elements as the system of communication (E2), obtaining financial resources for partnership (E3), and the decision-making process (E4). In the area of structure, two elements were identified: organization of the cell for collaboration (E5) and division of tasks, duties, and responsibilities (E6). In the area of people, the process of selecting employees (E7), competences and attitudes of employees is related to collaboration (E8) and leadership (E9). The area of the organization's environment is focused on external support for collaboration (E10) and reputation (E11).

This specific model was the basis for the development of a questionnaire, by means of which, on the basis of assessments made on the 5-point Likert scale, it is possible to assess the level of organization preparation for collaboration at a given stage. Achieving the higher stage is conditioned by the achievement of the lower stage The study was conducted on the basis of an interview questionnaire. The subject of the research was deliberately designated, as the features of selection and development perspectives in the future were indicated. The research was carried out in February 2018.

\section{The potential of Radom Airport for external collaboration}

Identification of individual elements of collaborative potential has shown that it is not homogeneous regarding the level of preparation of individual areas of the organization for collaboration (Figure 2). In the light of these objectives, one of the elements determining the model diagnosed is E1. Radom Airport has collaboration strategies and clear strategic goals available on the website. The goals of collaboration are evaluated, and employees are aware of them and know them.

The second area is defined as technology and consists of three key elements. Regarding element E2 - the communication system in the diagnosis was assessed 
at level 2. Only the flexibility condition of the communication pattern was not met, which results from the binding provisions of law that strictly define the manner of specific channels and communication tools, leaving no freedom in their selection. The next element is E3, which is acquiring financial resources for the entity.

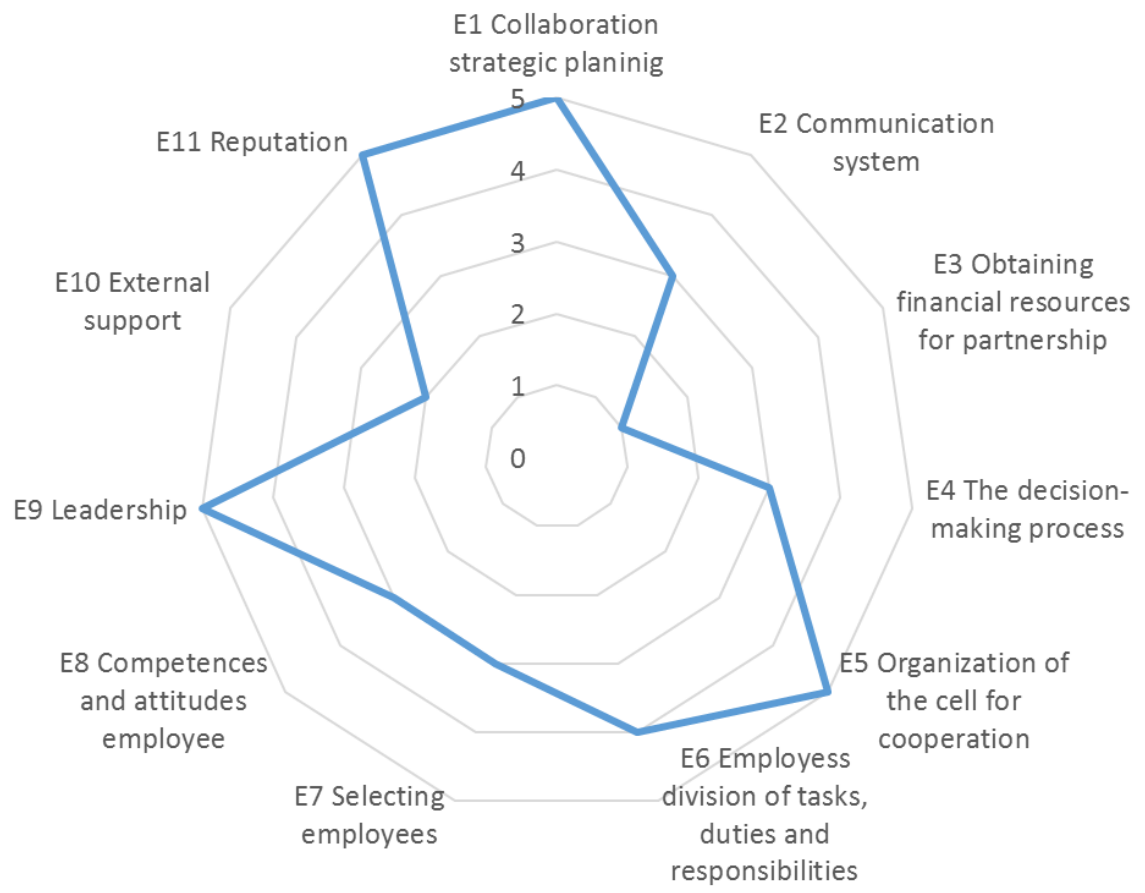

Figure 2. Collaborative potential PL Radom - results of the diagnosis in terms of quality

Source: Own elaboration

Radom Airport does not have procedures related to it, because it is still in the phase of infrastructure investments. Maintenance costs are not balanced from the company's revenues, and the only owner does not have Radom Airport included in budget expenditures. In connection with the above, there are no clear sources of financing, and thus there is no way to develop permanent rules for acquiring funds for external collaboration. Element E4, which is the decision-making process, is multi-layered and consists of several stages. It is supported by direct contacts using various media, but there are no records about the participative decision-making model in the template.

The next element to explore is the structure. It is an organization of the cell collaboration E5. It is an area interpreted as a conscious process of formation of an organizational unit cooperating at the level of an individual that identifies its hierarchical position and is adapted to it in the organizational area. Element E6 covers the principles of division of tasks and responsibilities. In Radom Airport, the heads of different units monitor the effectiveness of organizational solutions 
and improve them. The adaption of the structure is settled as the adaption of changes pertaining to the strategy modification and the objective of collaboration. Radom Airport has experience in assigning tasks and responsibilities. The scope of activities for the employees of the organizational unit is developed and documented, and updated if necessary in accordance with the competences and individual characteristics of the employees.

In the area of people, element E7 concerns selecting employees. However, there is no procedure for assigning tasks and responsibilities to co-operating members of the organizational unit because it is the copy of the template that is formally in force in accordance with the law. The next element E8 explains the competences and attitudes of employees, determining the level of preparation for collaboration of the organization employees. In Radom Airport, there is a procedure of selecting employees, who are required to know about the operational activities of the aerodrome and cooperating units; however, the selection procedure is not dependent on the detailed procedures of the organization Radom Airport is planning to collaborate with. Specialist training is organized when such collaboration is organized. The company does not have a developed employee incentive system that could shape an active attitude during collaboration. Nevertheless, element E9 of leadership specifies that the manager is an important element in the collaboration process. The manager presents a success-oriented attitude and influences the selection of employees. He also adopts an attitude supporting the functioning of the collaboration cells, aimed at solving problems.

In the environment area, element E10 - external support concerns the surroundings of Radom Airport. Because the only owner is the local government the Municipality of Radom City, the company is supported both economically and politically at the local level. Functioning is a strategic goal for local authorities, and there is a possibility of obtaining both financial and substantive support related to the implementation of objectives and tasks in collaboration with airlines. Radom Airport, however, does not have a developed procedure for analyzing the environment that allows for the use of assistance programs for collaboration implemented by the company. The last area in collaboration with partners is E11 reputation. Radom Airport is perceived very well by the airline it cooperates with. It has experience in collaboration promoted in various media and is aware of the need to constantly build its reputation in the field of external collaboration.

\section{Conclusions}

The above analysis shows that the collaboration process implemented at the airport is an element of management. It applies mainly to the process of making decisions about establishing relationships with partners, who, due to their character, have a huge influence on the functioning of the airport. This kind of collaboration is symbiotic, and the potential for such collaboration can be treated as one of the most important features of the airport.

In the analyzed example of the airport in Radom, not all areas are equally developed. The analysis of the planning process demonstrates that the collaboration 
works well. Partially, the structure was not too well adjusted to tasks and competences. People are the lowest rated area. Finally, although the potential in the sphere of leadership is large, it is necessary to evaluate the employees and shape their competences for collaboration.

The presented problem has a large research potential. Not only does the situation of the airport in question require deeper analysis, but it would be interesting to extend the research to other airports, which may contribute to the development of the theory of cooperative potential.

\section{Literature}

1. Bendkowski J. (1990), Ekonomika i zarzadzanie przemysłem, Wydawnictwo Politechniki Śląskiej, Gliwice.

2. Daft R.L. (2012), Management, South-Western Cengage Learning, Nelson Education, Nashville.

3. Drucker P.F. (2002), Myśli przewodnie Druckera, MT Biznes, Warszawa.

4. Ejdys J., Ustinovicius L., Stankevičienè J. (2015), Innovative Application of Contemporary Management Methods in a Knowledge-Based Economy - Interdisciplinarity in Science, "Journal of Business Economics and Management", Vol. 16(1), p. 261-274. DOI: 10.3846/ 16111699.2014 .986192

5. Griffin R.W. (1998), Podstawy zarzadzania organizacjami, PWN, Warszawa.

6. Heiman B., Nickerson J. (2002), Towards Reconciling Transaction Cost Economics and the Knowledge-based View of the Firm: The Context of Interfirm Collaborations, "International Journal of the Economics of Business", Vol. 9(1), p. 97-116. DOI: 10.1080/135715101 10103001

7. Illés B.Cs., Dunay A., Jelonek D. (2015), The Entrepreneurship in Poland and in Hungary. Future Entrepreneurs Education Perspective, "Polish Journal of Management Studies", Vol. 12, No. 1, p. 48-58.

8. Kalmi P. (2007), The Disappearance of Cooperatives from Economics Textbooks, "Cambridge Journal of Economics", Vol. 31(4), p. 625-647.

9. Koźmiński A.D., Jemielniak D. (2008), Zarządzanie od podstaw, WAiP, Warszawa.

10. Krzywda D., Krzywda J. (2016), The Role of Soft Skills in the Profession of Logisticians, "Supply Chain Management Journal", Vol. 7, No. 2, p. 75-83.

11. Levi Y., Davis P. (2008), Cooperatives as the "Enfants Terribles" of Economics: Some Implications for the Social Economy, "Journal of Socio-Economics", Vol. 37(6), p. 2178-2188. DOI: 10.1016/j.socec.2008.06.003

12. Marek S. (red.) (1999), Elementy nauki o przedsiębiorstwie, Fundacja na rzecz Uniwersytetu Szczecińskiego, Szczecin.

13. Nieżurawski L. (2005), Podstawy organizacji i zarządzania przedsiębiorstwem, Wydawnictwo Uniwersytetu Warmińsko-Mazurskiego, Olsztyn.

14. Nowicka K. (2011), Wspótpraca partnerska w tańcuchu dostaw, "Gospodarka Materiałowa i Logistyka", nr 6, p. 2-9.

15. Pierścieniak A. (2014). Wielowymiarowość zjawiska wspótpracy w organizacjach formalnych, "Ekonomika i Organizacja Przedsiębiorstwa", nr (11), p. 90-99.

16. Pierścieniak A. (2015), Potencjat organizacji do wspótpracy zewnętrznej-ujęcie teoretyczne i metodyka pomiaru, Prace Naukowe Wydziału Ekonomii Uniwersytetu Rzeszowskiego, seria: Monografie i Opracowania nr 18, Wydawnictwo Uniwersytetu Rzeszowskiego, Rzeszów.

17. Pierścieniak A. (2016), Metodologiczne wyzwania wobec badania wspótpracy organizacji, “Organizacja i Kierowanie", nr (1)171, p. 25-36. 
18. Pierścieniak A., Frejtag-Mika E. (2015), Wspótpraca jako narzędzie zarządzania w JST, "Przedsiębiorczość i Zarządzanie", t. 17, z. 2, cz. 2, p. 211-222.

19. Porter M.E. (1999), Strategia konkurencji, PWE, Warszawa.

20. Robson P.J., Bennett R.J. (2000), SME Growth: The Relationship with Business Advice and External Collaboration, "Small Business Economics", Vol. 15, No. 3, p. 193-208.

21. Romanowska M., Trocki M. (2002), Przedsiębiorstwo partnerskie, Difin, Warszawa.

22. Seroka-Stolka O., Krawczyk-Sokołowska I., Grabowska M. (2016), Environmental Management Models, [in:] Scientific Proceedings of the Scientific Technical Union of Mechanical Engineering, R. 24, Vol. 6(192), International Scientific Conference "High Technologies. Business. Society", Borovets, Bulgaria, p. 121-124.

23. Stoner J.A.F., Freeman R.E., Gilbert D.R. Jr. (2011), Kierowanie, PWE, Warszawa.

24. Surowiec A. (2015), Rola metody open-book accounting $w$ zarzadzaniu relacjami $w$ tańcuchach dostaw, [in:] Borowiecki R., Rojek T. (red.), Kształtowanie relacji partnerskich $i$ form współdziałania wspótczesnych przedsiębiorstw. Strategie - procesy - narzędzia, Fundacja Uniwersytetu Ekonomicznego w Krakowie, Kraków, p. 157-163.

25. Walczak W. (2012), Cele $i$ funkcje zarządzania $w$ teoriach naukowych a praktyka - próba diagnozy źródel występujacych rozbieżności, "E-mentor", $\mathrm{nr}$ 2, p. 19-29, http://www.e-mentor.edu.pl/artykul/index/numer/44/id/917 (accessed: 21.08.2017).

26. Zachorowska A. (2006), Ryzyko działalności inwestycyjnej przedsiębiorstw, PWE, Warszawa.

\section{POTENCJAŁ KOOPERACYJNY JAKO WSPARCIE ZARZĄDZANIA LOTNISKIEM (NA PRZYKLADZIE PL RADOM)}

Streszczenie: Współpraca to wymierny efekt wspólnych działań, a jej występowanie jest ściśle związane z rozwojem organizacji. Autorka przedstawia ją jako element zarządzania. Artykuł opiera się na identyfikacji i pomiarze potencjału organizacji do współpracy. Analiza przygotowania organizacji do współpracy została przedstawiona na przykładzie lotniska w Radomiu. Bazuje na metodologii badania potencjału organizacji do współpracy zewnętrznej, zbudowanej na podstawie klasycznego modelu organizacji według H.J. Leavitta. Wyznaczony model był podstawą do opracowania kwestionariusza, za pomocą którego, na podstawie ocen z 5-punktowej skali Likerta, można było ocenić poziom przygotowania organizacji do współpracy na danym etapie.

Słowa kluczowe: zarządzanie, współpraca, potencjał, lotnisko 